\title{
Lactic acid bacteria: reviewing the potential of a promising delivery live vector for biomedical purposes
}

\author{
Olivia Cano-Garrido ${ }^{1,2,3 \dagger}$, Joaquin Seras-Franzoso 1,2,3† and Elena Garcia-Fruitós 1,2,3,4*
}

\begin{abstract}
Lactic acid bacteria (LAB) have a long history of safe exploitation by humans, being used for centuries in food production and preservation and as probiotic agents to promote human health. Interestingly, some species of these Grampositive bacteria, which are generally recognized as safe organisms by the US Food and Drug Administration (FDA), are able to survive through the gastrointestinal tract (GIT), being capable to reach and colonize the intestine, where they play an important role. Besides, during the last decades, an important effort has been done for the development of tools to use $L A B$ as microbial cell factories for the production of proteins of interest. Given the need to develop effective strategies for the delivery of prophylactic and therapeutic molecules, LAB have appeared as an appealing option for the oral, intranasal and vaginal delivery of such molecules. So far, these genetically modified organisms have been successfully used as vehicles for delivering functional proteins to mucosal tissues in the treatment of many different pathologies including GIT related pathologies, diabetes, cancer and viral infections, among others. Interestingly, the administration of such microorganisms would suppose a significant decrease in the production cost of the treatments agents since being live organisms, such vectors would be able to autonomously amplify and produce and deliver the protein of interest. In this context, this review aims to provide an overview of the use of LAB engineered as a promising alternative as well as a safety delivery platform of recombinant proteins for the treatment of a wide range of diseases.
\end{abstract}

Keywords: Lactic acid bacteria, Delivery vector, QPS, Mucosal, Therapy, Treatment

\section{Background}

Most of the existing strategies for the treatment of diseases are focused on the delivery of naked molecules with a therapeutic activity, from chemically synthesized molecules to recombinant proteins produced in diverse platforms such as bacteria, yeast, insect cells and mammalian cells, among others [1]. However, these treatments require in many cases the use of invasive administration methods such as intravenous or subcutaneous injection of the molecule of interest to reach the targeted region [2]. Moreover, soluble purified proteins and other therapeutic

\footnotetext{
*Correspondence: elena.garcia@irta.cat

†Olivia Cano-Garrido and Joaquin Seras-Franzoso contributed equally to this work

${ }^{4}$ Present Address: Department of Ruminant Production, Institut de Recerca i Tecnologia Agroalimentàries (IRTA), Torre Marimon, Caldes de Montbui, 08140 Barcelona, Spain

Full list of author information is available at the end of the article
}

compounds frequently show low stability and/or poor efficiency in the organism forcing repeated administration [2], with the subsequent increase in the amount of needed pharmaceutical and the frequent derived increase in toxicity and cost of the treatment [2]. In the case of recombinant therapeutic proteins produced in microbial hosts, biosafety concerns are raised, mainly due to the possible remnants of pyrogenic or inflammatory contaminants that can trigger undesirable immunogenic responses [3]. Given the need to develop an alternative route for the administration, as well as a safety delivery platform, lactic acid bacteria (LAB) have appeared as an appealing option for the production and delivery of therapeutic molecules and antigens of interest [4]. This heterogeneous group of Gram-positive bacteria, in contrast to Gram-negative bacteria such as E. coli, do not contain lipopolysaccarides (LPS) attached to the cell membrane. The absence of such endotoxins avoids the generation of an anaphylactic shock 
when $L A B$ are administered in humans [3]. In this regard, it should be noted that LAB have a long history of safe use by humans, being used for centuries in food production and preservation [5-7]. In this context, some strains have also a long record in their use as probiotic bacteria producer of metabolites and macromolecules able to maintain and promote human health $[5,8]$. Then, LAB have been classified as food grade microorganisms [generally recognized as safe (GRAS) organisms by the US Food and Drug Administration (FDA)] and fulfill criteria of the qualified presumption of safety (QPS) according to the European Food Safety Authority (EFSA). Besides, it is important to stress that an exhaustive work has been done in developing different tools for the recombinant protein production using LAB as cell factories [9]. The development of these tools has made possible the development of LAB able to secrete the protein of interest to the extracellular environment, becoming a key aspect when evaluating the potential of these bacteria for mucosal targeting of therapeutic molecules [4] (Table 1). Alternatively, approaches based on protein display anchored to the bacteria cell wall have also been tested [10], being a system that, even not being as effective as secreted protein in terms of protein expression levels, gives a higher protection to the protein in front of degrading and denaturing agents (Table 1). In consequence, these microorganisms can be used for oral, intranasal or vaginal administration for protein delivery purposes, minimizing any potential side effect associated with the classical parenteral or subcutaneous administration of proteins, simultaneously reducing the dose needed.

Although LAB include microorganisms from different genus such as Leuconostoc, Lactococcus, Lactobacillus, Pedicoccus and Streptococcus, Lactococcus lactis has been the most widely used considering cloning and production of recombinant proteins [11]. L. lactis has been deeply characterized, being the first one whose genome was fully sequenced. In addition, it is an expression system easy to manipulate with many cloning and expression systems available. The most widely used protein expression system for L. lactis is the NICE (Nisin Controlled Expression) system, based on the control of a strong nisin inducible promoter $\left(\mathrm{P}_{\text {nisA }}\right)$, which has several advantages. The expression of the gene of interest is tightly regulated and high expression levels are achieved using a food-grade molecule (nisin) as inducer. [12]. Although several proteins with biotechnological or biomedical interest produced in L. lactis using inducible plasmids have been proved in both experimental models and clinical trials [13], a prior induction of protein production have been required in these cases before the administration of the recombinant bacteria. For that reason, other inducible promoters that do not require the addition of any external inducer have been developed not only for $L$. lactis, but also for other LAB such as Lactobacillus paracasei. These promoters are directly induced in situ, for example once bacteria suffer environmental stresses such as heat-stress (body temperature is some degrees higher than bacteria optimal growth temperature) [14] or acid-stress (because of the stomach fluids) [15], enabling the recombinant production of the protein of interest without the need for adding an external inducer. In this regard and considering that $L$. paracasei respond to stress by synthesising chaperones such as groESL [14], an Stress-Inducible Controlled Expression (SICE) system based on the groESL operon promoter has also been described [15]. The development of promoters that do not depend on the addition of external inducers have allowed to take an important qualitative leap towards the use of LAB as protein delivery vectors. In this context and aiming to take another step forward, constitutive promoters are also being extensively studied. These constitutive promoters make possible to get a maintained expression of the protein of interest over time without the need of any type of inducer. Currently it has been widely explored, being possible to find an important number of examples that have already been tested for protein delivery purposes specially with L. lactis, but also with L. paracasei, Lactobacillus casei, Lactobacillus plantarum, Bifidobacterium breve and Streptococcus gordonii (Table 1).

Thus, the use of food grade microorganisms as recombinant protein cell factories [9] and delivery platforms at the same time, is a promising approach $[6,11]$. Briefly, the administration of such microorganisms would also suppose a significant decrease in the production cost of the drugs as being live organisms, these live vectors would be able to autonomously synthesize and deliver the prophylactic or therapeutic protein of interest. Moreover, it is possible to simultaneously produce different proteins in the same bacteria [16]. Altogether has turned them into an attractive alternative not only to intravenous administration of naked recombinant proteins, but also to other classical delivery systems for mucosal targeting, such as attenuated pathogens, liposomes and microparticles [10]. Thus, here, is intended to provide an overview of the use of genetically modified food grade organisms engineered as attractive vehicles for delivering functional proteins to mucosal tissues for the treatment of a wide range of pathologies such as GIT related pathologies as well as some types of cancer and viral infections, among others (Fig. 1).

\section{Review}

\section{Autoimmune diseases}

Effective therapeutic approaches for autoimmune diseases like GIT related diseases and diabetes are urgently 
Table 1 Recombinant proteins produced in LAB for biomedical purposes

\begin{tabular}{|c|c|c|c|c|c|c|}
\hline LAB & Application & $\begin{array}{l}\text { Recombinant } \\
\text { protein }\end{array}$ & Expression vector & Promoter & Protein display & References \\
\hline Lactococcus lactis & IDB & $\begin{array}{c}\text { Anti-TNFalpha } \\
\text { nanobodies }\end{array}$ & pTREX-derived & P1 (pH dependent) & Secreted & {$[22]$} \\
\hline Lactococcus lactis & IDB & Trefoil Factors (TFF) & pTREX-derived & P1 (pH dependent) & Secreted & [23] \\
\hline Lactococcus lactis & IDB & $\begin{array}{l}\text { Low calcium } \\
\text { response V (LcrV) }\end{array}$ & pNZYR-derived & $\mathrm{P}_{\text {Usp45 }}$ (constitutive) & Secreted & [21] \\
\hline $\begin{array}{l}\text { Lactobacillus gasseri/ } \\
\text { Lactobacillus casei }\end{array}$ & IDB & $\begin{array}{l}\text { Superoxide Dis- } \\
\text { mutase (SOD) }\end{array}$ & $\begin{array}{l}\text { pSodA } \\
\text { plLKSsodA }\end{array}$ & sodA native promoter & - & {$[39,40]$} \\
\hline Lactococcus lactis & IDB & $\mathrm{IL}-10$ & $\begin{array}{l}\text { Cromosome inte- } \\
\text { grated }\end{array}$ & $P_{\text {thyA }}$ (constitutive) & Secreted & [26] \\
\hline Lactococcus lactis & IDB & IL-27 & pT1NX-derived & P1 (pH dependent) & Secreted & {$[35]$} \\
\hline Lactococcus lactis & $\mathrm{IBD}$ & Murine IL-10 & pLB263 & $P_{\text {groesL }}$ (Inducible) & Secreted & {$[15]$} \\
\hline $\begin{array}{l}\text { Lactococcus lactis/ } \\
\text { Lactobacillus casei }\end{array}$ & $\begin{array}{l}\text { IDB/colorectal } \\
\text { Cancer }\end{array}$ & Catalase & $\begin{array}{l}\text { pSEC:KatE/ } \\
\text { pLEM415mnkat }\end{array}$ & $\begin{array}{l}P_{\text {nisA }} \text { (inducible) } / P_{\text {Idh }} \\
\text { (constitutive) }\end{array}$ & Cytoplasmatic & {$[24,25]$} \\
\hline Lactococcus lactis & Type 1 diabetes & $\begin{array}{l}\text { Pro Insulin/(GAD)- } \\
\quad 65 / / L-10\end{array}$ & pT1NX-derived & P1 (pH dependent) & Secreted & [44] \\
\hline Lactococcus lactis & Type 1 diabetes & HSP65-6P277 & $\begin{array}{r}\text { pCYT:HSP65-6P277/ } \\
\text { pHJ: HSP65-6P277 }\end{array}$ & $\begin{array}{l}P_{\text {nisA }} \text { (inducible)/con- } \\
\text { stitutive }\end{array}$ & $\begin{array}{l}\text { Cytoplasmatic/ } \\
\text { secreted }\end{array}$ & [43] \\
\hline Lactococcus lactis & Type 1 diabetes & GAD65 and IA-2 & - & - & Secreted & {$[46]$} \\
\hline Lactococcus lactis & Diabetes & $\begin{array}{l}\text { Single-chain insulin } \\
\text { analog, SCl-57 }\end{array}$ & pNZPnisA:uspSCI-57 & $P_{\text {nisA }}($ inducible) & Secreted & [41] \\
\hline Lactococcus lactis & Type 2 diabetes & $\begin{array}{l}\text { Glucagon like pep- } \\
\text { tide-1 (GLP-1) }\end{array}$ & pUBGLP-1 & P1 (pH dependent) & Secreted & {$[42]$} \\
\hline Lactococcus lactis & Cancer & HPV-16 E7 antigen & pLB263 & $P_{\text {groEsL }}$ (inducible) & Secreted & {$[15]$} \\
\hline $\begin{array}{l}\text { Bifidobacterium } \\
\text { longum }\end{array}$ & Breast cancer & Cytosine Deaminase & pBLES100-S-eCD & - & - & [57] \\
\hline $\begin{array}{l}\text { Bifidobacterium } \\
\text { adolescentis }\end{array}$ & Cancer & Endostatin & pBV220-derived & $\begin{array}{l}P_{R} P_{L} \text { (thermoinduc- } \\
\text { ible) }\end{array}$ & Cytoplasmatic & {$[58]$} \\
\hline Bifidobacterium breve & $\begin{array}{l}\text { Cancer treatment } \\
\text { study tool }\end{array}$ & Luciferase & pLux MC3 & $P_{\text {help }}$ (constitutive) & Cytoplasmatic & [59] \\
\hline Lactococcus lactis & Cervical cancer & HPV-16 E7 & - & $P_{\text {nisA }}$ (Inducible) & Anchored & [61] \\
\hline Lactococcus lactis & Cervical cancer & HPV-16 E7 & pMG36e & P32 (constitutive) & Cytoplasmatic & {$[62]$} \\
\hline $\begin{array}{l}\text { Lactococcus lactis/ } \\
\text { Lactobacillus casei }\end{array}$ & Cervical cancer & HPV-16E7 & - & - & Anchored & [63] \\
\hline Bacillus subtilis & Cervical cancer & HPV33 L1 & plCHPV33L1-NS/B & Pxylose (inducible) & Intracellular & [74] \\
\hline $\begin{array}{l}\text { Lactobacillus para- } \\
\text { casei }\end{array}$ & $\begin{array}{l}\text { Bacillus anthracis } \\
\text { infection }\end{array}$ & Antibody fragment & $\begin{array}{l}\text { pAF100-derived/ } \\
\text { pAF400-derived/ } \\
\text { pAF900-derived }\end{array}$ & $P_{a p f}$ (constitutive) & $\begin{array}{l}\text { Secreted/attached/ } \\
\text { cell anchored }\end{array}$ & [85] \\
\hline $\begin{array}{l}\text { Lactobacillus para- } \\
\text { casei }\end{array}$ & Rotavirus infection & Antibody fragment & pLP501-derived & $P_{\text {Idh }}$ (constitutive) & $\begin{array}{l}\text { Secreted/cell } \\
\text { anchored }\end{array}$ & [87] \\
\hline $\begin{array}{l}\text { Bifidubacterium } \\
\text { longum }\end{array}$ & $\begin{array}{l}\text { Enterovirus } 71 \text { infec- } \\
\text { tion }\end{array}$ & VP1 & pBBADs-VP1 & - & - & [109] \\
\hline $\begin{array}{l}\text { Bifidubacterium } \\
\text { longum }\end{array}$ & Hepatitis C infection & HCV-NS3 peptide & - & - & Cell anchored & [110] \\
\hline Lactococcus lactis & $\begin{array}{l}\text { Staphylococal infec- } \\
\text { tion }\end{array}$ & $\begin{array}{l}\text { Staphylocococal } \\
\text { nuclease }\end{array}$ & pLB263 & $P_{\text {groEsL }}$ (inducible) & Secreted & [15] \\
\hline $\begin{array}{l}\text { Lactobacillus acido- } \\
\text { philus }\end{array}$ & HIV infection & Gag & pTRK1035 & (Constitutive) & Cell anchored & {$[82]$} \\
\hline Lactobacillus jensenii & HIV infection & $\begin{array}{l}\text { two-domain CD4 } \\
\text { (2D CD4) proteins }\end{array}$ & POSEL144 & $P_{23}$ (constitutive) & Secreted & [69] \\
\hline Lactobacillus casei & Tetanus & $\begin{array}{l}\text { Tetanus toxin frag- } \\
\text { ment C (TTC) }\end{array}$ & pLP401-TTFC & P amylase (inducible) & Cell anchored & {$[72]$} \\
\hline Lactobacillus casei & Tetanus & $\begin{array}{l}\text { Tetanus toxin frag- } \\
\text { ment C (TTC) }\end{array}$ & pLP501-TTFC & $P_{\text {ldh }}$ (constitutive) & Cell anchored & {$[72]$} \\
\hline $\begin{array}{l}\text { Lactobacillus plan- } \\
\text { tarum }\end{array}$ & Tetanus & $\begin{array}{l}\text { Tetanus toxin frag- } \\
\text { ment C (TTC) }\end{array}$ & pMEC160 & $P_{\text {Idh }}$ (constitutive) & Cell anchored & [70] \\
\hline
\end{tabular}


Table 1 continued

\begin{tabular}{|c|c|c|c|c|c|c|}
\hline LAB & Application & $\begin{array}{l}\text { Recombinant } \\
\text { protein }\end{array}$ & Expression vector & Promoter & Protein display & References \\
\hline $\begin{array}{l}\text { Streptococcus } \\
\text { gordonii }\end{array}$ & $\begin{array}{l}\text { Clostridium tetani } \\
\text { infection }\end{array}$ & $\begin{array}{l}\text { Tetanus toxin frag- } \\
\text { ment C }\end{array}$ & pSMB158 & (constitutive) & Cell anchored & [111] \\
\hline $\begin{array}{l}\text { Lactobacillus acido- } \\
\text { philus }\end{array}$ & $\begin{array}{l}\text { Helicobacter pylori } \\
\text { infection }\end{array}$ & Adhesin Hp0410 & pMG36e & - & Cytoplasmatic & {$[76]$} \\
\hline Lactococcus lactis & Rotavirus infection & VP8 & pNZ8048 & $P_{\text {nisA }}$ (inducible) & $\begin{array}{l}\text { Secreted/cell } \\
\text { anchored/cyto- } \\
\text { plasmatic }\end{array}$ & [112] \\
\hline Lactococcus lactis & Malaria & $\mathrm{MSP} \mathrm{1}_{19}$ & pL2-PSGT & - & Cytoplasmatic & [81] \\
\hline Lactococcus lactis & Peanut allergy & Arah 2 & pNZ8148 & $P_{\text {nisA }}$ (inducible) & $\begin{array}{l}\text { Secreted/cell } \\
\text { anchored/cyto- } \\
\text { plasmatic }\end{array}$ & [93] \\
\hline Lactococcus lactis & Dust mite allergy & Der p2 & pNZ8148 & $P_{\text {nisA }}$ (inducible) & $\begin{array}{l}\text { Secreted/cell } \\
\text { anchored/cyto- } \\
\text { plasmatic }\end{array}$ & [94] \\
\hline $\begin{array}{l}\text { Streptococcus } \\
\text { gordonii }\end{array}$ & $\begin{array}{l}\text { Giardia lamblia infec- } \\
\text { tion }\end{array}$ & $\begin{array}{l}\text { cyst wall protein } 2 \\
\text { (CWP2) }\end{array}$ & pSMB104 & (constitutive) & Cell anchored & [73] \\
\hline Lactobacillus zeae & $\begin{array}{l}\text { Streptococcus } \\
\text { mutants infection }\end{array}$ & ScFv protein & pLP402-scFv & - & Cell anchored & {$[68]$} \\
\hline Lactococcus lactis & $\begin{array}{l}\text { Streptococcus pneu- } \\
\text { moniae infection }\end{array}$ & $\begin{array}{l}\text { Pneumococcal sur- } \\
\text { face protein A }\end{array}$ & pTREX1 & P1 (pH dependent) & Cytoplasmatic & [113] \\
\hline Lactobacillus casei & $\begin{array}{l}\text { SARS-associated } \\
\text { coronavirus infec- } \\
\text { tion }\end{array}$ & $\begin{array}{l}\text { PgsA and spike } \\
\text { protein }\end{array}$ & pHAT & $P_{\text {HCE }}$ (constitutive) & Cell anchored & [114] \\
\hline $\begin{array}{l}\text { Lactobacillus acido- } \\
\text { philus }\end{array}$ & Chiken anemia virus & VP1 & pETacmA1 & - & Cell anchored & [71] \\
\hline Lactococcus lactis & Avian influenza virus & $\begin{array}{l}\text { hemagglutinin } 1 \\
\text { (HA1) }\end{array}$ & pMG36e & - & Cytoplasmatic & [91] \\
\hline Lactococcus lactis & $\begin{array}{l}\text { Leishmania major } \\
\text { infection }\end{array}$ & $\begin{array}{l}\text { LACK } \\
\text { LACK + IL12 }\end{array}$ & pDL-PnisA & $\mathrm{P}_{\text {nisA }}$ (inducible) & $\begin{array}{l}\text { Secreted/cell } \\
\text { anchored/cyto- } \\
\text { plasmatic }\end{array}$ & {$[88]$} \\
\hline Lactobacillus casei & $\begin{array}{l}\text { Pancreatic necrosis } \\
\text { virus (IPNV) }\end{array}$ & VP2NP3 & $\mathrm{pG} 1 / \mathrm{pG} 2$ & Pxylose (inducible) & Secreted & {$[89,90]$} \\
\hline Lactococcus lactis & Body weight control & Leptin & pSEC:lep & $P_{\text {nis }}$ (Inducible) & - & [97] \\
\hline $\begin{array}{l}\text { Saccharomyces } \\
\text { cerevisiae }\end{array}$ & Hypercalcemia & Salmon calcitonin & pAGA2-sCT & $P_{\text {GAL1 }}$ (inducible) & Cell anchored & {$[115]$} \\
\hline
\end{tabular}

needed and the development of oral formulation is an imperative need. Oral administration is the most preferred route since it is well accepted by patients, becoming a promising alternative for drug delivery of such autoimmune diseases.

\section{GIT related diseases: Crohn's disease and ulcerative colitis}

Inflammatory bowel disease (IBD) is an idiopathic disorder consisting in the inflammation of the GIT. It is believed that this abnormal condition is due to an uncontrolled immune response against the gut microflora $[17,18]$. Although the underlying cause is still unclear $[19,20]$, it is known that environmental and genetic factors have an important role in these complex diseases. Crohn's disease and ulcerative colitis are included in this general IBD definition and the patients that suffer these chronic diseases usually require lifelong and costly treatments with sever sideeffects. Moreover, in many cases, therapeutic agents used fail, and despite medical treatment, surgery is needed. In this sense, the use of recombinant microorganisms, that fulfill the QPS standards, overexpressing any molecule able to alleviate inflammation could be an attractive and alternative treatment, since their safe profile and administration pathway would allow an easy incorporation of the treatment to the patient's routine improving their comfort. Some strategies have been proposed using proteins such as low-calcium $\mathrm{V}$ antigen (LcrV) [21], anti-TNF $\alpha$ nanobodies [22], trefoil factors (TFF) [23], catalase [24, 25] and IL-10 [26] using L. lactis as microbial delivery vector (Table 1). All these proteins have been successfully produced by the L. lactis platform ameliorating, upon their oral administration, the inflammatory response of IBD animal models. 


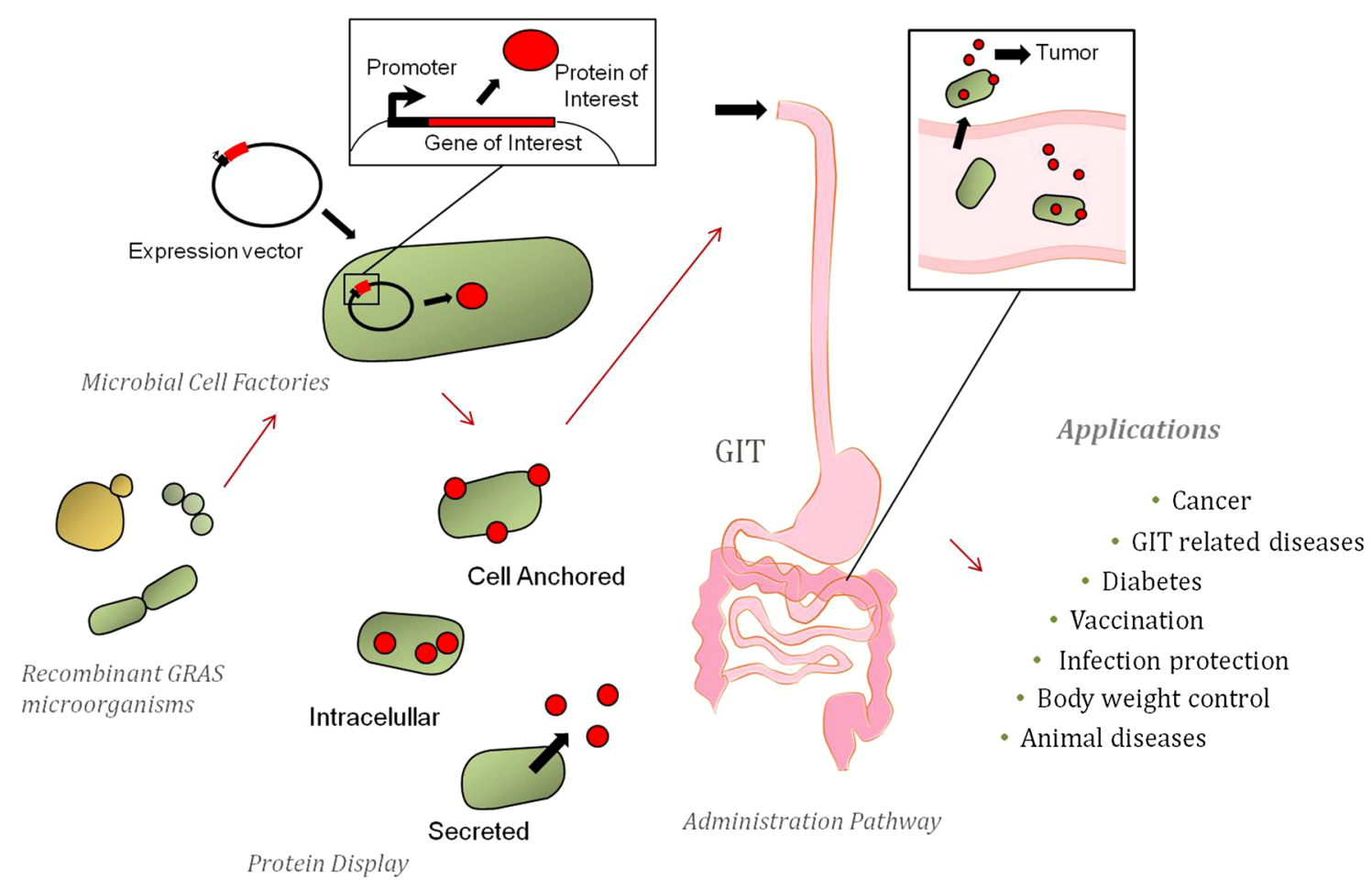

Fig. 1 Schematic representation of the use of $\angle A B$ for biomedical applications using the oral administration pathway

Noteworthy, the success of these approaches is related to the delivery of the therapeutic agent at the mucosa level. A clear example is provided by the orally administered L. lactis secreting anti-TNF $\alpha$ nanobodies [22]. This nanobody secretion platform has an efficacy similar to that observed with the established therapy (Infliximab, Remicade), based on the intravenous infusion of anti-TNF $\alpha$ [22, 27-30]. However, contrary to what occurs by the systemic infusion, the oral administration of $L$. lactis strains secreting anti-TNF $\alpha$ is cost effective and lacks adverse effects [22].

LAB with potential in IBD treatment share the objective of reducing gut inflammation. Nevertheless, depending on the recombinant protein to be delivered the affected pathway differs. Thus, anti-TNF $\alpha$ nanobodies would reduce inflammation by neutralizing the action of the pro-inflammatory cytokine TNF $\alpha$. Expression of IL-10, which is a regulatory cytokine, would decrease inflammation thanks to its antinflammatory activity [26], while the use of enzymes such as catalase would act on the inflammatory response derived from the presence of reactive oxygen species (ROS) [24, 25].

The approach that probably has been more extensively studied is the delivery of IL-10 produced in $L$. lactis. In fact, L. lactis secreting IL-10 has been submitted to clinical trials for the treatment of Crohn disease
(ClinicalTrials.gov Identifier: NCT00729872) [23, 26, 31-34]. Nevertheless, and despite the very promising results observed in mice, the clinical trial revealed the mentioned approach inefficient (ClinicalTrials.gov Identifier: NCT00729872). This failure is thought as a consequence of a low final concentration of IL-10 in the GIT. In this regard, it has been recently proposed using IL-27, a pleiotropic cytokine, in order to get a broader response due to its immunosuppressive role as well as the capacity to induce IL-10 expression [35].

Besides, elafin, an endogenous protease inhibitor, has also been orally administered using $L$. lactis and $L$. case $i$ as delivery vectors, observing a restoration of colon homeostasis in mice $[11,36,37]$. Elastin, which is diminished in patients with IBD, has a pleiotropic and antiinflammatory role in healthy human gut [11, 36, 37]. Recently, two other anti-inflammatory molecules named secretory leukocyte protease inhibitor (SLPI) and the enzyme 15-lipoxygenase-1 (15-LOX-1) secreted by $L$. lactis have shown the ability to notably reduce the intestinal inflammation in mice [37, 38].

Other models used for the local display in the mice gut of therapeutic protein are Lactobacillus gasseri and $L$. casei both expressing superoxide dismutase (SOD) [39, 40]. As it happens with catalase, SOD action neutralizes ROS species and their derived inflammatory effect. 


\section{Diabetes}

Some articles have also been published exploring the potential of food-grade bacteria for the treatment of diabetes (Table 1). In this context, $\mathrm{Ng}$ and collaborators proved that $L$. lactis is able to secrete an insulin analog in vitro [41], promoting the expected biological effect on target adipocytes. Some years later, Agarwal et al. have described a successful in vivo assay with rats based on the oral delivery of glucagon like peptide-1 (GLP-1) using again L. lactis as delivery platform [42]. Briefly, GLP-1 has emerged as a promising therapeutic peptide for type 2 diabetes treatment, being a compound that is synthesized by the GIT for the maintenance of glucose homeostasis. Up to now, GLP-1 has been administered through injection, being necessary one administration at least once a week. Interestingly, Agarwal et al. have observed that once recombinant $L$. lactis secreting GLP-1 is orally administered in rats, a reduction in blood glucose levels and an important increase in insulin take place [42].

Nowadays, it is widely accepted that current treatments based on insulin replacement for type 2 diabetes have important weak aspects [42]. On the one hand, the autoimmune response that impairs $\beta$-cells in pancreas is not inhibited [42]. On the other hand, insulin injection cannot prevent important associated complications to diabetes. Therefore, different therapeutic approaches based on immunotherapies are also being explored, being the use of antigen-based immunotherapies the most promising for this autoimmune disease. A 24 amino-acid peptide derived from human HSP60 has demonstrated to be a convenient alternative for the modulation of the immunological attack on $\beta$-cells in mouse [43]. This peptide was successfully orally administered using recombinant L. lactis as delivery carrier, having a clear effect on the improvement of glucose tolerance and in the reduction of insulinitis and hyperglycemia [43]. In addition, another study has been recently published describing the administration of a L. lactis strain delivering antigens such as pro-insulin or glutamic acid decarboxylase in combination with IL-10 and anti-CD3 as an appealing method to improve the induction of antigen-specific tolerance for the treatment of the type 1 diabetes [23, 44, 45]. Another study has been recently followed the oral administration of $L$. lactis secreting two major auto-antigens of type 1 diabetes, named glutamic acid decarboxylase (GAD65) and tyrosine phosphatase-like protein ICA512 (IA-2) in mouse models $[23,46]$. In this study, modified versions of GAD65 and IA-2 have been successfully used in combination with human IL-10 cytokine $[23,46]$.

\section{Cancer}

Cancer has a huge relevance in human health due to its growing incidence in developed countries. The strategies for effective cancer treatment under study are countless and the use of LAB has recently appeared in this field.

Cancer development and progression have been broadly related with chronic inflammation processes produced by external factors such as infection, radiation, unbalanced diet, obesity, tobacco or the exposure to other environmental pollutants [47]. Thus, in principle, any strategy aimed to treat chronic inflammation could produce also a positive outcome in cancer occurrence. In this regard, the use of LAB organisms for colorectal cancer prevention has been explored using mainly colorectal cancer murine models [48]. Some examples of the strains used with this purpose are Bifidobacterium lactis [49], L. casei strain Shirota [50], B. longum BB536 [51], Lactobacillus acidophilus Delvo Pro LA-1 [52], Lactobacillus rhamnosus GG [53] or Propionibacterium freudenreichii [54] but many others rendered similar results, showing a significant decrease in cancer development. It is important to note although the significant number of LAB showing promise in in vitro and in animal models that no conclusive studies have been carried out in humans.

On the other hand, interesting studies regarding biodistribution of the microbial vectors in mice models illustrates the capacity of some food grade species to reach solid tumors, where they are able to accumulate and proliferate after intravenous administration [55, 56]. This behavior has been related with the hypoxic environment exhibited in the tumors. In such atmosphere anaerobic bacteria selectively grow $[55,56]$. This capacity has been exploited in B. longum to propose an anti-breast cancer strategy based on the recombinant production of cytosine deaminase in the solid tumor after the intravenous administration of the microbial vector. The enzyme combined with the administration of the 5-fluorocytosine (5FC) would result in a locally high concentration of the reaction product, 5-fluorouracyl (5FU) [57]. Another example using Bifidobacterium adolescentis expressing a recombinant endostatin showed how this safe vector was able to selectively inhibit angiogenesis and tumor growth in tumor mice models after its intravenous administration [58]. These studies reinforce the capability of these microorganisms' genera, classified according to QPS standards, as potential drug delivery systems for cancer treatment. The protein secreted by the live vector will be more stable than those naked soluble proteins intravenously administered. However, as previously mentioned, the intravenous injection of LAB have important adverse effects. Thus, the delivery of such live vectors at mucosal level would be much more appropriate. In this context, the potential use as orally administered drug delivery vector with a natural selectivity for solid tumors has also been explored (Table 1). Recombinant $B$. breve orally administered in mice are able to effectively translocate 
the GIT and colonize solid tumors at the same levels than intravenously administered ones [59]. Interestingly, the crossing of the GIT by the recombinant B. breve, involving an increased permeability of the GIT epithelia didn't promote the crossing of potentially pathogenic bacteria present in the regular gut flora [59].

Besides, LAB can also be orally administered taking advantage of their natural niche in the body to develop prophylactic strategies against colon cancer without the need of the GIT translocation. In this sense a recombinant $L$. lactis producing catalase has shown a protective effect in chemically induced colon cancer in mice models [60]. Tumor cells are characterized by an increased production of ROS such as hydrogen peroxide $\left(\mathrm{H}_{2} \mathrm{O}_{2}\right)$, that actively participate in enhancing tumour invasion and proliferation. Thus, the administration of L. lactis producing catalase, an enzyme with an antioxidant activity, decreases $\mathrm{H}_{2} \mathrm{O}_{2}$ levels and, consequently, reduces colonic damage and inflammation [60]. Interestingly, since the oxidative stress associated to an increase of ROS levels is also characteristic of gastrointestinal pathologies, the approach developed in this study can be used also as a therapy for the treatment of IBD. Recently, some articles have been published using the administration of L. lactis expressing human papillomavirus E7 oncoprotein (HPV16 E7) for the treatment of cervical cancer. In one of these articles, E7 protein has been produced by a secretion SICE plasmid and administrated to mice with tumours. Results show that administration of recombinant bacteria provokes a slightly diminution of tumour volume and an antigen-specific immune response [15]. In other studies these food-grade bacteria have been administered in mice via intranasal expressing HPV-16 E7 anchored to its surface [61, 62]. In one case, E7 protein has been combined with calreticulin-E7 administration inducing $>80 \%$ of tumour suppression in mice [61]. In a second approach, recombinant lactococci have been tested for the simultaneous delivery of E7 protein and murine interleukin-12 (IL-12) DNA [62], observing that this new strategy combining the delivery of both the therapeutic molecules and antigens has a high potential. Finally, E7 protein effect has also been investigated using $L$. case $i$ as mucosal delivery vector in mice [63].

\section{Infectious diseases}

Historically vaccines have been based on attenuated pathogenic microorganisms $[64,65]$. However, this approach has three important drawbacks: (a) difficulties on the construction of stable attenuated mutants; (b) presence of residual virulence in attenuated pathogens; (c) risk of genetic reassortment between the vaccine strain and the wild type. Besides, although pure antigens have also been used for vaccination purposes, these molecules have a low or non-existing immune response, especially because their rapid degradation and their poor adsorption in vivo [66]. Thus, aiming to find an alternative strategy, non-pathogenic LAB have also been explored as mucosal vaccines. Many approaches have been proposed in order to produce and present different antigens [23, 67]. Most of them have been developed in L. lactis, but also there are works using other LAB such as Lactobacillus zeae [68], Lactobacillus jensenii [69], L. plantarum [70], L. acidophilus [71], L. casei [72], Streptococcus gordinii [73], and Bacillus subtilis [74] (Table 1). It should be noted that several Lactobacillus species have been exploited in this field, being some of them able to attach and colonise the gastrointestinal mucosa, being acid-resistant and biletolerant [75]. Besides, the presence of these bacteria may naturally inhibit the pathogenic colonization of pathogenic microorganisms such as Helicobacter pylori [76]. However, although Lactobacillus seems to be one of the best candidates for immunization purposes, protein expression levels achieved are still lower than those obtained with L. Lactis $[66,77]$. Since low protein yields cannot induce an immune response strong enough to trigger protection against infective agents, an optimal antigen presentation is required. That is possible with a sudden high concentration of the antigen as such obtained with inducible approaches [67]. Nevertheless, given that it is common to find either insolubility or toxicity of some recombinant proteins during overexpression, constitutive plasmids can be a good alternative [78]. The use of constitutive plasmids is a much safer approach, being not necessary to add any external inducer to get the desired amount of protein. The use of constitutive plasmids is exemplified by the expression of SspA and SspB antigens from $S$. gordonii, a major colonizer of oral hard and soft tissues, on the cell surface of L. lactis using P1 promoter. Both antigens were successfully expressed and anchored in the cell wall and their in vitro ability to adhere to $S$. gordonii surface was proven [79]. Another example is the slpA constitutive promoter based on S-layer protein. The very strong expression signal of S-layer has been proven for the secretion of $\beta$-lactamase using $L$. lactis, L. brevis, $L$. plantarum, L. gasseri and L. casei [80] and of Merozoite surface protein 1 (MSP1) from Plasmodium falciparum using L. lactis [81]. Interestingly, this last study proves the potential of recombinant $L$. lactis as an effective oral vaccination alternative against malaria [81]. In vivo studies with MSP1 antigen show its capacity to confer protection to the vaccinated animals [81]. Furthermore, the combination of the antigen with adjuvant molecules have been studied also aiming to achieve an increased efficiency of these vaccines. An example is the coexpression of HIV-1 with the flagellin (FliC) of Salmonella enterica 
in $L$. acidophilus. The results show that Gag (antigen against HIV-1) and FliC coexpression promotes Gagspecific IgA-producing cells at the local mucosa [82]. Another study has been reported aiming to develop a vaccine against the chicken anemia virus (CAV) [71]. VP1 antigen produced in E. coli was fused to the binding domain of AcmA, the major autolysin of L. lactis cell wall, at N-terminal aiming to enhance the Lactobacillus immunization ability. In this case, the authors observed that the fusion protein remains on the cell surface at least 5 days and that the oral administration induced a moderate immune response in chicken $[4,71]$.

Bifidobacterium is another appealing food-grade vector. It is abundant in human gut, well recognised as probiotic and with the ability to activate Th1 cell-mediated immune responses without antigen presentation [83]. Because of its biletolerance, a regulated promoter based on upstream sequence of bet $A$ (a bile-inducible transporter gene) has been recently developed in order to control gene expression specifically in the intestinal tract [84]. However, it should be noted that Bifidobacterium has a strict anaerobic metabolism making harder the experimentation with it.

A part from IBD, diabetes and cancer, other diseases have been targeted using food grade bacteria. Among them, interesting examples can be found in the control of microbial infections (Table 1). Regarding microbial infections neutralizing antibody fragments expressed in L. paracase $i$ and L. acidphilus have been shown able to provide protection against Bacillus anthracis $[85,86]$ and L. paracasei against rotavirus [87] in mice. These studies open possibilities of generating alternative Lactobacilli producing antibodies against other infectious diseases affecting the GIT.

Besides, it is important to note that $\mathrm{LAB}$ and other organisms classified as QPS by EFSA are useful mucosal delivery vectors to treat not only human diseases but also animal diseases. Just as an example, LAB have been used to combat Leishmaniasis [88]. Moreover, Lactobacilli have also been used to design live vaccines to combat a wide range of diseases such as pancreatic necrosis virus (IPNV, a pathogen that infects wild and cultured salmonids) $[89,90]$, a highly pathogenic avian influenza (HPAI) [91], and porcine epidemic diarrhea virus (PEDV) [92].

\section{Allergic and other diseases}

Some studies have combined the bacterial effect with an expressed antigen either for food hypersensitivity or aero-allergens. The administration of L. lactis displaying the recombinant allergen intracellularly, in the extracellular space or cell wall-anchored show its capacity to modulate the Th2-based specific antibody responses, in the case of the allergen Ara h 2 against peanut allergic
[93] and the Der p2 allergen against the dust mite allergy [94]. In the second study, the authors also observed a diminution in the cellular infiltration and inflammatory response.

It has been demonstrated that obesity and gut microbiota composition strongly correlates $[95,96]$. In addition, some LAB such as Lactobacillus and Bifidobacterium are able to improve obesity in both murine models and humans [96]. In this context, obesity has also been targeted in mice models by the delivery of recombinant leptin using LAB. Leptin is a hormone with a crucial role in body weight control. In this case, the capability of this protein to carry out its action was improved by the intranasal administration of engineered L. lactis secreting the hormone observing a significant loss in body weight as well as a reduction in food intake in the treated animals [97].

Another example is the administration of cytokinessecreting $\mathrm{LAB}$ as prophylaxis therapy, being the delivery of IL-10 for inflammatory bowel diseases [98] and of IL-12 for asthma [99] just a couple of examples [100].

Finally it is necessary to stress out that although most of the applications referred to in this revision are envisaged using LAB, also eukaryotic expression systems with a safe profile can be found in the literature. This possibility would result of interest in the cases of therapeutic proteins requiring complex post-translational modifications to became fully functional [101]. In this regard, prokaryotic cell factories would lack the machinery to perform the required processing of the recombinant protein [101]. A nice example is found in recombinant Saccharomyces cerevisiae. This yeast has been proposed as a vehicle to secrete proteins or peptides with a therapeutic effect in the gut [102]. In this sense, an orally recombinant S. cerevisiae displaying a salmon recombinant calcitonin on the yeast surface prompted a decrease in calcium levels in hypercalcemic rats after oral administration.

\section{Adverse side-effects of $L A B$}

In the previous sections we have been focusing the attention on the positive effect of $\mathrm{LAB}$ as live vectors for protein delivery. However, it is important to stress that LAB are genetically modified organisms (GMOs). GMOs are widely accepted and well stablish in food industry. However, important regulatory concerns need to be addressed for its use as therapeutic vechicles. Specifically, LAB are based on expression systems carrying antibiotic resistance genes as a selection marker [103]. It has been described that these live vectors could transfer its antibiotic resistances to intestinal microbiota. Although this is a really rare event that has not been reported in this field, it is an important issue to be considered. The application of $\mathrm{LAB}$ as live vectors opens a broad and interesting 
field of possibilities, but regulatory measures have to be considered to ensure the safety of the used strains. Up to now, some alternative and innovative selection markers have already been developed, being some of them successfully tested and positively evaluated by several health authorities [23, 34, 103]. However, these alternative and safe selection markers need to be further explored to finally ensure the real possibility of using such strains for the problems listed above.

Besides, it should be noted that some adverse effects of LAB have been reported [104-106]. This indicates that, despite the positive therapeutic effects of these microorganisms and the low number of adverse effects registered, they are not completely safe. This information should be contextualized, since the adverse effects were observed in high risk groups such as critically ill and/or immune-compromised patients, critically sick infants, and postoperative and hospitalized patients [104]. Sepsis, fungemia and GI ischemia are the main harmful effects of LAB described [104]. Briefly, in this vulnerable populations $\mathrm{LAB}$ could interfere with the microflora giving rise to opportunistic infections and finally to bacterimia, fungimia or other medical complications. In addition, there are strong evidences proving that LAB, when used as probiotics, have anti-inflammatory effects. However, many reports also describe pro-inflammatory effects caused by such group of bacteria [107, 108]. This means that probiotic effect of LAB is strain dependent, being a factor to be considered for the choice of host strains for therapeutic applications.

In general terms, one can conclude that the safety of LAB is widely supported by the long tradition of use of such microbes. This safety record leads us to conclude that risk-benefit ratio in the prevention and treatment of multiple disease states is overall really high, being the studies reporting adverse effects scarce. Nonetheless, risks and benefits should be carefully considered in each situation, especially on those health-compromised patients. Besides, considering that adverse events are poorly documented, an accurate safety report including pathogenicity, infectivity, virulence and toxicity would help the scientific community taking decisions and more solid conclusions [105].

\section{Conclusions}

The irruption of nanotechnology and other innovative approaches have allowed the development of alternatives to the classical medicine aiming to overcome its inherent limitations. In this regard, the exploitation of LAB as recombinant probiotics expressing any protein of interest has strongly burst them as a promising alternative for the treatment of a wide range of diseases. The mucosal, needle-free, administration of therapeutic molecules of interest gives an added value to LAB. Besides, it has been shown that the application of these recombinant probiotic bacteria via intranasal, oral or genital would have a dual effect: a direct effect designed for the treatment of a specific disease through the expression of a recombinant protein, combined with the indirect and general effect that some of these safe bacteria have in health. Additionally, the administration of such live delivery vectors is easier and relatively inexpensive compared to injectable treatments, being a large-scale production affordable [66]. Interestingly, up to now the use of LAB has been successfully tested for a wide range of medical applications, mainly using animal models, being the treatment of autoimmune diseases the most intensively investigated. These food-grade bacteria have also been proposed as excellent candidates for vaccination. There is still a lot to be done and a long way to reach the market, but all the articles published up to now let us suggest LAB as a promising delivery vector for a vast range of biomedical applications.

The next step will be the detailed study of all factors that could become an important bottleneck in the future implementation of LAB as effective live vectors delivering proteins of interest in situ. Important safety and regulatory issues still need to be addressed in depth, but some significant steps have already been done in this context. Small trials using auxotroph strains have been positively evaluated for the treatment of patients with Chron's disease $[26,34]$. Other aspects such as an extensive study of real cost and efficiency are still outstanding questions that need to be answered.

\section{Authors' contributions}

All authors have contributed to this review from their complementing areas of expertise. All authors read and approved the final manuscript.

\section{Author details}

${ }^{1}$ Institut de Biotecnologia i de Biomedicina, Universitat Autònoma de Barcelona, Bellaterra, 08193 Cerdanyola del Vallès, Spain. ${ }^{2}$ Departament de Genètica i de Microbiologia, Universitat Autònoma de Barcelona, Bellaterra, 08193 Cerdanyola del Vallès, Spain. ${ }^{3}$ CIBER de Bioingeniería, Biomateriales y Nanomedicina (CIBER-BBN), Bellaterra, 08193 Cerdanyola del Vallès, Spain. ${ }^{4}$ Present Address: Department of Ruminant Production, Institut de Recerca i Tecnologia Agroalimentàries (IRTA), Torre Marimon, Caldes de Montbui, 08140 Barcelona, Spain.

\section{Acknowledgements}

The authors acknowledge the financial support Granted to EGF from INIA, MINECO, Spain (RTA2012-00028-C02-02), from Agència de Gestió d'Ajuts Universitaris i de Recerca (2014SGR-132) and from the Centro de Investigación Biomédica en Red (CIBER) de Bioingeniería, Biomateriales y Nanomedicina financed by the Instituto de Salud Carlos III with assistance from the European Regional Development Fund. OC-G received a PhD fellowship from MECD and EGF a post-doctoral fellowship from INIA (DOC-INIA, INIA, MINECO). We are also indebted to the Protein Production Platform (CIBER-BBN) for helpful assistance (http://www.ciber-bbn.es/es/ programas/89-plataforma-de-produccion-de-proteinas-ppp).

Compliance with ethical guidelines

\section{Competing interests}

The authors declare that they have no competing interests. 
Received: 7 January 2015 Accepted: 10 August 2015 Published online: 16 September 2015

\section{References}

1. Ferrer-Miralles N, Domingo-Espin J, Corchero JL, Vazquez E, Villaverde A (2009) Microbial factories for recombinant pharmaceuticals. Microb Cell Fact 8:17

2. Hillery AM (2011) Drug delivery and targeting: for pharmacists and pharmaceutical scientists. Tailor \& Francis, UK

3. Rueda F, Cano-Garrido O, Mamat U, Wilke K, Seras-Franzoso J, GarciaFruitos E, Villaverde A (2014) Production of functional inclusion bodies in endotoxin-free Escherichia coli. Appl Microbiol Biotechnol 98:9229-9238

4. Wells JM (2011) Immunomodulatory mechanisms of lactobacilli. Microb Cell Factories 10(Suppl 1):S17

5. Gareau MG, Sherman PM, Walker WA (2010) Probiotics and the gut microbiota in intestinal health and disease. Nat Rev Gastroenterol Hepatol 7:503-514

6. Konings WN, Kok J, Kuipers OP, Poolman B (2000) Lactic acid bacteria: the bugs of the new millennium. Curr Opin Microbiol 3:276-282

7. Ross RP, Morgan S, Hill C (2002) Preservation and fermentation: past, present and future. Int J Food Microbiol 79:3-16

8. Salminen S, Nybom S, Meriluoto J, Collado MC, Vesterlund S, El-Nezami $H$ (2010) Interaction of probiotics and pathogens-benefits to human health? Curr Opin Biotechnol 21:157-167

9. Garcia-Fruitos E (2012) Lactic acid bacteria: a promising alternative for recombinant protein production. Microb Cell Fact 11:157

10. LeBlanc JG, Aubry C, Cortes-Perez NG, de Moreno de LeBlanc A, Vergnolle N, Langella P, Azevedo V, Chatel JM, Miyoshi A, Bermudez-Humaran LG (2013) Mucosal targeting of therapeutic molecules using genetically modified lactic acid bacteria: an update. FEMS Microbiol Lett 344:1-9

11. Bermudez-Humaran LG, Aubry C, Motta JP, Deraison C, Steidler L, Vergnolle N, Chatel JM, Langella P (2013) Engineering lactococci and lactobacilli for human health. Curr Opin Microbiol 16:278-283

12. Mierau I, Kleerebezem M (2005) 10 years of the nisin-controlled gene expression system (NICE) in Lactococcus lactis. Appl Microbiol Biotechnol 68:705-717

13. Wells J (2011) Mucosal vaccination and therapy with genetically modified lactic acid bacteria. Annu Rev Food Sci Technol 2:423-445

14. Desmond C, Fitzgerald GF, Stanton C, Ross RP (2004) Improved stress tolerance of GroESL-overproducing Lactococcus lactis and probiotic Lactobacillus paracasei NFBC 338. Appl Environ Microbiol 70:5929-5936

15. Benbouziane B, Ribelles P, Aubry C, Martin R, Kharrat P, Riazi A, Langella P, Bermudez-Humaran LG (2013) Development of a Stress-Inducible Controlled Expression (SICE) system in Lactococcus lactis for the production and delivery of therapeutic molecules at mucosal surfaces. J Biotechnol 168:120-129

16. Moore RJ, Stewart DJ, Lund K, Hodgson AL (2001) Vaccination against ovine footrot using a live bacterial vector to deliver basic protease antigen. FEMS Microbiol Lett 194:193-196

17. Baumgart DC, Carding SR (2007) Inflammatory bowel disease: cause and immunobiology. Lancet 369:1627-1640

18. Bernstein CN (2015) Treatment of IBD: where we are and where we are going. Am J Gastroenterol 110:114-126

19. Strober W, Fuss I, Mannon P (2007) The fundamental basis of inflammatory bowel disease. J Clin Invest 117:514-521

20. Papa A, Mocci G, Bonizzi M, Felice C, Andrisani G, Papa G, Gasbarrini A (2009) Biological therapies for inflammatory bowel disease: controversies and future options. Expert Rev Clin Pharmacol 2:391-403

21. Foligne B, Dessein R, Marceau M, Poiret S, Chamaillard M, Pot B, Simonet M, Daniel C (2007) Prevention and treatment of colitis with Lactococcus lactis secreting the immunomodulatory Yersinia LcrV protein. Gastroenterology 133:862-874

22. Vandenbroucke $K$, de Haard H, Beirnaert E, Dreier T, Lauwereys M, Huyck L, Van Huysse J, Demetter P, Steidler L, Remaut E et al (2010) Orally administered L. lactis secreting an anti-TNF nanobody demonstrate efficacy in chronic colitis. Mucosal Immunol 3:49-56
23. Vandenbroucke K, Hans W, Van Huysse J, Neirynck S, Demetter P, Remaut E, Rottiers P, Steidler L (2004) Active delivery of trefoil factors by genetically modified Lactococcus lactis prevents and heals acute colitis in mice. Gastroenterology 127:502-513

24. Rochat T, Miyoshi A, Gratadoux JJ, Duwat P, Sourice S, Azevedo V, Langella $P(2005)$ High-level resistance to oxidative stress in Lactococcus lactis conferred by Bacillus subtilis catalase KatE. Microbiology 151:3011-3018

25. Rochat T, Bermudez-Humaran L, Gratadoux JJ, Fourage C, Hoebler C, Corthier G, Langella P (2007) Anti-inflammatory effects of Lactobacillus casei BL23 producing or not a manganese-dependant catalase on DSSinduced colitis in mice. Microb Cell Fact 6:22

26. Braat H, Rottiers $P$, Hommes DW, Huyghebaert N, Remaut E, Remon JP, van Deventer SJ, Neirynck S, Peppelenbosch MP, Steidler L (2006) A phase I trial with transgenic bacteria expressing interleukin-10 in Crohn's disease. Clin Gastroenterol Hepatol 4:754-759

27. Van Assche G, Vermeire S, Rutgeerts $P$ (2009) Infliximab therapy for patients with inflammatory bowel disease: 10 years on. Eur J Pharmacol 623(Suppl 1):S17-S25

28. Riegert-Johnson DL, Godfrey JA, Myers JL, Hubmayr RD, Sandborn WJ, Loftus EV Jr (2002) Delayed hypersensitivity reaction and acute respiratory distress syndrome following infliximab infusion. Inflamm Bowel Dis 8:186-191

29. Kakavas S, Balis E, Lazarou V, Kouvela M, Tatsis G (2013) Respiratory failure due to infliximab induced interstitial lung disease. Heart Lung 42:480-482

30. Vaz JL, Andrade CA, Pereira AC, Martins Mde F, Levy RA (2013) Systematic review of infliximab-induced autoantibodies and systemic lupus erythematosus. Rev Bras Reumatol 53:358-364

31. Huibregtse IL, SnoeckV, de Creus A, Braat H, De Jong EC, Van Deventer SJ, Rottiers P (2007) Induction of ovalbumin-specific tolerance by oral administration of Lactococcus lactis secreting ovalbumin. Gastroenterology 133:517-528

32. Steidler L, Hans W, Schotte L, Neirynck S, Obermeier F, Falk W, Fiers W, Remaut E (2000) Treatment of murine colitis by Lactococcus lactis secreting interleukin-10. Science 289:1352-1355

33. Steidler L, Neirynck S, Huyghebaert N, Snoeck V, Vermeire A, Goddeeris B, Cox E, Remon JP, Remaut E (2003) Biological containment of genetically modified Lactococcus lactis for intestinal delivery of human interleukin 10. Nat Biotechnol 21:785-789

34. Rottiers P, De Smedt T, Steidler L (2009) Modulation of gut-associated lymphoid tissue functions with genetically modified Lactococcus lactis. Int Rev Immunol 28:465-486

35. Hanson ML, Hixon JA, Li W, Felber BK, Anver MR, Stewart CA, Janelsins BM, Datta SK, Shen W, McLean MH, Durum SK (2014) Oral delivery of IL-27 recombinant bacteria attenuates immune colitis in mice. Gastroenterology 146(210-221):e213

36. Motta JP, Bermudez-Humaran LG, Deraison C, Martin L, Rolland C, Rousset P, Boue J, Dietrich G, Chapman K, Kharrat P et al (2012) Food-grade bacteria expressing elafin protect against inflammation and restore colon homeostasis. Sci Transl Med 4:158ra144

37. Bermudez-Humaran LG, Motta JP, Aubry C, Kharrat P, Rous-Martin L, Sallenave JM, Deraison C, Vergnolle N, Langella P (2015) Serine protease inhibitors protect better than IL-10 and TGF-beta anti-inflammatory cytokines against mouse colitis when delivered by recombinant lactococci. Microb Cell Fact 14:26

38. de Moreno de LeBlanc A, Del Carmen S, Chatel JM, Miyoshi A, Azevedo V, Langella P, Bermudez-Humaran LG, LeBlanc JG (2015) Current review of genetically modified lactic acid bacteria for the prevention and treatment of colitis using murine models. Gastroenterol Res Pract 2015:146972

39. Watterlot L, Rochat T, Sokol H, Cherbuy C, Bouloufa I, Lefevre F, Gratadoux JJ, Honvo-Hueto E, Chilmonczyk S, Blugeon S et al (2010) Intragastric administration of a superoxide dismutase-producing recombinant Lactobacillus casei BL23 strain attenuates DSS colitis in mice. Int J Food Microbiol 144:35-41

40. Carroll IM, Andrus JM, Bruno-Barcena JM, Klaenhammer TR, Hassan HM, Threadgill DS (2007) Anti-inflammatory properties of Lactobacillus gasseri expressing manganese superoxide dismutase using the interleukin 10-deficient mouse model of colitis. Am J Physiol Gastrointest Liver Physiol 293:G729-G738 
41. Ng DT, Sarkar CA (2011) Nisin-inducible secretion of a biologically active single-chain insulin analog by Lactococcus lactis NZ9000. Biotechnol Bioeng 108:1987-1996

42. Agarwal P, Khatri P, Billack B, Low WK, Shao J (2014) Oral delivery of glucagon like peptide-1 by a recombinant Lactococcus lactis. Pharm Res 31:3404-3414

43. Ma Y, Liu J, Hou J, Dong Y, Lu Y, Jin L, Cao R, Li T, Wu J (2014) Oral administration of recombinant Lactococcus lactis expressing HSP65 and tandemly repeated $\mathrm{P} 277$ reduces the incidence of type I diabetes in non-obese diabetic mice. PLoS One 9:e105701

44. Takiishi T, Korf H, Van Belle TL, Robert S, Grieco FA, Caluwaerts S, Galleri L, Spagnuolo I, Steidler L, Van Huynegem Ket al (2012) Reversal of autoimmune diabetes by restoration of antigen-specific tolerance using genetically modified Lactococcus lactis in mice. J Clin Invest 122:1717-1725

45. Robert S, Gysemans C, Takiishi T, Korf H, Spagnuolo I, Sebastiani G, Van Huynegem K, Steidler L, Caluwaerts S, Demetter P et al (2014) Oral delivery of glutamic acid decarboxylase (GAD)-65 and IL10 by Lactococcus lactis reverses diabetes in recent-onset NOD mice. Diabetes 63:2876-2887

46. Robert S, Van Huynegem K, Gysemans C, Mathieu C, Rottiers P, Steidler $L$ (2015) Trimming of two major type 1 diabetes driving antigens, GAD65 and IA-2, allows for successful expression in Lactococcus lactis. Benef Microbes 6:591-601

47. Aggarwal BB, Vijayalekshmi RV, Sung B (2009) Targeting inflammatory pathways for prevention and therapy of cancer: short-term friend, longterm foe. Clin Cancer Res 15:425-430

48. Azcarate-Peril MA, Sikes M, Bruno-Barcena JM (2011) The intestinal microbiota, gastrointestinal environment and colorectal cancer: a putative role for probiotics in prevention of colorectal cancer? Am J Physiol Gastrointest Liver Physiol 301:G401-G424

49. Le Leu RK, Hu Y, Brown IL, Woodman RJ, Young GP (2010) Synbiotic intervention of Bifidobacterium lactis and resistant starch protects against colorectal cancer development in rats. Carcinogenesis 31:246-251

50. Yamazaki K, Tsunoda A, Sibusawa M, Tsunoda Y, Kusano M, Fukuchi K, Yamanaka M, Kushima M, Nomoto K, Morotomi M (2000) The effect of an oral administration of Lactobacillus casei strain shirota on azoxymethane-induced colonic aberrant crypt foci and colon cancer in the rat. Oncol Rep 7:977-982

51. Kulkarni N, Reddy BS (1994) Inhibitory effect of Bifidobacterium longum cultures on the azoxymethane-induced aberrant crypt foci formation and fecal bacterial beta-glucuronidase. Proc Soc Exp Biol Med 207:278-283

52. Mclntosh GH, Royle PJ, Playne MJ (1999) A probiotic strain of L. acidophilus reduces $\mathrm{DMH}$-induced large intestinal tumors in male SpragueDawley rats. Nutr Cancer 35:153-159

53. Goldin BR, Gualtieri LJ, Moore RP (1996) The effect of Lactobacillus GG on the initiation and promotion of $\mathrm{DMH}$-induced intestinal tumors in the rat. Nutr Cancer 25:197-204

54. Lan A, Lagadic-Gossmann D, Lemaire C, Brenner C, Jan G (2007) Acidic extracellular $\mathrm{pH}$ shifts colorectal cancer cell death from apoptosis to necrosis upon exposure to propionate and acetate, major end-products of the human probiotic propionibacteria. Apoptosis 12:573-591

55. Malmgren RA, Flanigan CC (1955) Localization of the vegetative form of Clostridium tetani in mouse tumors following intravenous spore administration. Cancer Res 15:473-478

56. Kimura NT, Taniguchi S, Aoki K, Baba T (1980) Selective localization and growth of Bifidobacterium bifidum in mouse tumors following intravenous administration. Cancer Res 40:2061-2068

57. Fujimori M (2006) Genetically engineered bifidobacterium as a drug delivery system for systemic therapy of metastatic breast cancer patients. Breast Cancer 13:27-31

58. Li X, Fu GF, Fan YR, Liu WH, Liu XJ, Wang JJ, Xu GX (2003) Bifidobacterium adolescentis as a delivery system of endostatin for cancer gene therapy: selective inhibitor of angiogenesis and hypoxic tumor growth. Cancer Gene Ther 10:105-111

59. Cronin M, Morrissey D, Rajendran S, El Mashad SM, van Sinderen D O'Sullivan GC, Tangney M (2010) Orally administered bifidobacteria as vehicles for delivery of agents to systemic tumors. Mol Ther 18:1397-1407
60. de Moreno de LeBlanc A, LeBlanc JG, Perdigon G, Miyoshi A, Langella P Azevedo V, Sesma F (2008) Oral administration of a catalase-producing Lactococcus lactis can prevent a chemically induced colon cancer in mice. J Med Microbiol 57:100-105

61. Rangel-Colmenero BR, Gomez-Gutierrez JG, Villatoro-Hernandez J, Zavala-Flores LM, Quistian-Martinez D, Rojas-Martinez A, Arce-Mendoza AY Guzman-Lopez S, Montes-de-Oca-Luna R, Saucedo-Cardenas O (2014) Enhancement of Ad-CRT/E7-mediated antitumor effect by preimmunization with L. lactis expressing HPV-16 E7. Viral Immunol 27:463-467

62. Li Y, Li X, Liu H, Zhuang S, Yang J, Zhang F (2014) Intranasal immunization with recombinant Lactococci carrying human papillomavirus E7 protein and mouse interleukin-12 DNA induces E7-specific antitumor effects in C57BL/6 mice. Oncol Lett 7:576-582

63. Ribelles P, Benbouziane B, Langella P, Suarez JE, Bermudez-Humaran LG (2013) Protection against human papillomavirus type 16-induced tumors in mice using non-genetically modified lactic acid bacteria displaying E7 antigen at its surface. Appl Microbiol Biotechnol 97:1231-1239

64. Koo OK, Amalaradjou MA, Bhunia AK (2012) Recombinant probiotic expressing Listeria adhesion protein attenuates Listeria monocytogenes virulence in vitro. PLoS One 7:e29277

65. Formal SB, Baron LS, Kopecko DJ, Washington O, Powell C, Life CA (1981) Construction of a potential bivalent vaccine strain: introduction of Shigella sonnei form I antigen genes into the galE Salmonella typhi Ty21a typhoid vaccine strain. Infect Immun 34:746-750

66. Bermudez-Humaran LG, Kharrat P, Chatel JM, Langella P (2011) Lactococci and lactobacilli as mucosal delivery vectors for therapeutic proteins and DNA vaccines. Microb Cell Fact 10(Suppl 1):S4

67. Bahey-El-Din M, Gahan CG, Griffin BT (2010) Lactococcus lactis as a cell factory for delivery of therapeutic proteins. Curr Gene Ther 10:34-45

68. Kruger C, Hu Y, Pan Q, Marcotte H, Hultberg A, Delwar D, van Dalen PJ, Pouwels PH, Leer RJ, Kelly CG et al (2002) In situ delivery of passive immunity by lactobacilli producing single-chain antibodies. Nat Biotechnol 20:702-706

69. Chang TL, Chang CH, Simpson DA, Xu Q, Martin PK, Lagenaur LA, Schoolnik GK, Ho DD, Hillier SL, Holodniy M et al (2003) Inhibition of HIV infectivity by a natural human isolate of Lactobacillus jensenii engineered to express functional two-domain CD4. Proc Natl Acad Sci USA 100:11672-11677

70. Reveneau N, Geoffroy MC, Locht C, Chagnaud P, Mercenier A (2002) Comparison of the immune responses induced by local immunizations with recombinant Lactobacillus plantarum producing tetanus toxin fragment $C$ in different cellular locations. Vaccine 20:1769-1777

71. Moeini H, Rahim RA, Omar AR, Shafee N, Yusoff K (2011) Lactobacillus acidophilus as a live vehicle for oral immunization against chicken anemia virus. Appl Microbiol Biotechnol 90:77-88

72. Maassen CB, Laman JD, den Bak-Glashouwer MJ, Tielen FJ, van HoltenNeelen JC, Hoogteijling L, Antonissen C, Leer RJ, Pouwels PH, Boersma WJ, Shaw DM (1999) Instruments for oral disease-intervention strategies: recombinant Lactobacillus casei expressing tetanus toxin fragment $C$ for vaccination or myelin proteins for oral tolerance induction in multiple sclerosis. Vaccine 17:2117-2128

73. Lee P, Faubert GM (2006) Oral immunization of BALB/c mice by intragastric delivery of Streptococcus gordonii-expressing Giardia cyst wall protein 2 decreases cyst shedding in challenged mice. FEMS Microbiol Lett 265:225-236

74. Baek JO, Seo JW, Kwon O, Park SM, Kim CH, Kim IH (2012) Production of human papillomavirus type $33 \mathrm{~L} 1$ major capsid protein and virus-like particles from Bacillus subtilis to develop a prophylactic vaccine against cervical cancer. Enzyme Microb Technol 50:173-180

75. Zhang M, Zhang H, Li Y, Qi W, Wang X, Wang J (2013) Inhibitory effect of Lactobacillus acidophilus on Helicobacter hepaticus in vitro. World J Microbiol Biotechnol 29:499-504

76. Hongying F, Xianbo W, Fang Y, Yang B, Beiguo L (2014) Oral immunization with recombinant Lactobacillus acidophilus expressing the adhesin Hp0410 of Helicobacter pylori induces mucosal and systemic immune responses. Clin Vaccine Immunol 21:126-132

77. Seegers JF (2002) Lactobacilli as live vaccine delivery vectors: progress and prospects. Trends Biotechnol 20:508-515

78. de Vos WM (2011) Systems solutions by lactic acid bacteria: from paradigms to practice. Microb Cell Fact 10(Suppl 1):S2 
79. Holmes AR, Gilbert C, Wells JM, Jenkinson HF (1998) Binding properties of Streptococcus gordonii SspA and SspB (antigen I/II family) polypeptides expressed on the cell surface of Lactococcus lactis MG1363. Infect Immun 66:4633-4639

80. Savijoki K, Kahala M, Palva A (1997) High level heterologous protein production in Lactococcus and Lactobacillus using a new secretion system based on the Lactobacillus brevis S-layer signals. Gene 186:255-262

81. Zhang ZH, Jiang PH, Li NJ, Shi M, Huang W (2005) Oral vaccination of mice against rodent malaria with recombinant Lactococcus lactis expressing MSP-1 (19). World J Gastroenterol 11:6975-6980

82. Kajikawa A, Zhang L, Long J, Nordone S, Stoeker L, LaVoy A, Bumgardner S, Klaenhammer T, Dean G (2012) Construction and immunological evaluation of dual cell surface display of HIV-1 gag and Salmonella enterica serovar Typhimurium FliC in Lactobacillus acidophilus for vaccine delivery. Clin Vaccine Immunol 19:1374-1381

83. Lopez P, Gueimonde M, Margolles A, Suarez A (2010) Distinct bifidobacterium strains drive different immune responses in vitro. Int J Food Microbiol 138:157-165

84. Ruiz L, Alvarez-Martin P, Mayo B, de los Reyes-Gavilan CG, Gueimonde M, Margolles A (2012) Controlled gene expression in bifidobacteria by use of a bile-responsive element. Appl Environ Microbiol 78:581-585

85. Andersen KK, Marcotte H, Alvarez B, Boyaka PN, Hammarstrom L (2011) In situ gastrointestinal protection against anthrax edema toxin by single-chain antibody fragment producing lactobacilli. BMC Biotechnol 11:126

86. Mohamadzadeh M, Duong T, Sandwick SJ, Hoover T, Klaenhammer TR (2009) Dendritic cell targeting of Bacillus anthracis protective antigen expressed by Lactobacillus acidophilus protects mice from lethal challenge. Proc Natl Acad Sci USA 106:4331-4336

87. Pant N, Hultberg A, Zhao Y, Svensson L, Pan-Hammarstrom Q, Johansen K, Pouwels PH, Ruggeri FM, Hermans P, Frenken L et al (2006) Lactobacilli expressing variable domain of Ilama heavy-chain antibody fragments (lactobodies) confer protection against rotavirus-induced diarrhea. J Infect Dis 194:1580-1588

88. Hugentobler F, Di Roberto RB, Gillard J, Cousineau B (2012) Oral immunization using live Lactococcus lactis co-expressing LACK and IL-12 protects BALB/C mice against Leishmania major infection. Vaccine 30:5726-5732

89. Min L, Li-Li Z, Jun-Wei G, Xin-Yuan Q, Yi-Jing L, Di-Qiu L (2012) Immunogenicity of Lactobacillus-expressing VP2 and VP3 of the infectious pancreatic necrosis virus (IPNV) in rainbow trout. Fish Shellfish Immunol 32:196-203

90. Zhao LL, Liu M, Ge JW, Qiao XY, Li YJ, Liu DQ (2012) Expression of infectious pancreatic necrosis virus (IPNV) VP2-VP3 fusion protein in Lactobacillus casei and immunogenicity in rainbow trouts. Vaccine 30:1823-1829

91. Wang Z, Gao J, Yu Q, Yang Q (2012) Oral immunization with recombinant Lactococcus lactis expressing the hemagglutinin of the avian influenza virus induces mucosal and systemic immune responses. Future Microbiol 7:1003-1010

92. Liu DQ, Ge JW, Qiao XY, Jiang YP, Liu SM, Li YJ (2012) High-level mucosal and systemic immune responses induced by oral administration with Lactobacillus-expressed porcine epidemic diarrhea virus (PEDV) S1 region combined with Lactobacillus-expressed N protein. Appl Microbiol Biotechnol 93:2437-2446

93. Ren C, Zhang Q, Wang G, Ai C, Hu M, Liu X, Tian F, Zhao J, Chen Y, Wang $M$ et al (2014) Modulation of peanut-induced allergic immune responses by oral lactic acid bacteria-based vaccines in mice. Appl Microbiol Biotechnol 98:6353-6364

94. Ai C, Zhang Q, Ren C, Wang G, Liu X, Tian F, Zhao J, Zhang H, Chen YQ, Chen W (2014) Genetically engineered Lactococcus lactis protect against house dust mite allergy in a BALB/c mouse model. PLoS One 9:e109461

95. An HM, Park SY, Lee do K, Kim JR, Cha MK, Lee SW, Lim HT, Kim KJ, Ha NJ (2011) Antiobesity and lipid-lowering effects of Bifidobacterium spp. in high fat diet-induced obese rats. Lipids Health Dis 10:116

96. Yin YN, Yu QF, Fu N, Liu XW, Lu FG (2010) Effects of four Bifidobacteria on obesity in high-fat diet induced rats. World J Gastroenterol 16:3394-3401
97. Bermudez-Humaran LG, Nouaille S, Zilberfarb V, Corthier G, Gruss A, Langella P, Issad T (2007) Effects of intranasal administration of a leptinsecreting Lactococcus lactis recombinant on food intake, body weight, and immune response of mice. Appl Environ Microbiol 73:5300-5307

98. Frossard CP, Steidler L, Eigenmann PA (2007) Oral administration of an IL-10-secreting Lactococcus lactis strain prevents food-induced IgE sensitization. J Allergy Clin Immunol 119:952-959

99. Wu C, Yang G, Bermudez-Humaran LG, Pang Q, Zeng Y, Wang J, Gao $X$ (2006) Immunomodulatory effects of IL-12 secreted by Lactococcus lactis on Th1/Th2 balance in ovalbumin (OVA)-induced asthma model mice. Int Immunopharmacol 6:610-615

100. de Azevedo MSP, Innocentin S, Dorella FA, Rocha CS, Mariat D, Pontes DS, Miyoshi A, Azevedo V, Langella P, Chatel JM (2013) Immunotherapy of allergic diseases using probiotics or recombinant probiotics. J Appl Microbiol 115:319-333

101. Jenkins N (2007) Modifications of therapeutic proteins: challenges and prospects. Cytotechnology 53:121-125

102. Blanquet $S$, Antonelli R, Laforet L, Denis S, Marol-Bonnin S, Alric M (2004) Living recombinant Saccharomyces cerevisiae secreting proteins or peptides as a new drug delivery system in the gut. J Biotechnol 110:37-49

103. Peterbauer C, Maischberger T, Haltrich D (2011) Food-grade gene expression in lactic acid bacteria. Biotechnol J 6:1147-1161

104. Didari T, Solki S, Mozaffari S, Nikfar S, Abdollahi M (2014) A systematic review of the safety of probiotics. Expert Opin Drug Saf 13:227-239

105. Doron S, Snydman DR (2015) Risk and safety of probiotics. Clin Infect Dis 60(Suppl 2):S129-S134

106. Ishibashi N, Yamazaki S (2001) Probiotics and safety. Am J Clin Nutr 73:465S-470S

107. Plaza-Diaz J, Gomez-Llorente C, Fontana L, Gil A (2014) Modulation of immunity and inflammatory gene expression in the gut, in inflammatory diseases of the gut and in the liver by probiotics. World J Gastroenterol 20:15632-15649

108. Villena J, Aso H, Kitazawa H (2014) Regulation of toll-like receptorsmediated inflammation by immunobiotics in bovine intestinal epitheliocytes: role of signaling pathways and negative regulators. Front Immunol 5:421

109. Yu Z, Huang Z, Sao C, Huang Y, Zhang F, Ma G, Chen Z, Zeng Z, Qiwen D, Zeng W (2013) Oral immunization of mice using Bifidobacterium longum expressing VP1 protein from enterovirus 71. Arch Virol 158:1071-1077

110. Takei S, Omoto C, Kitagawa K, Morishita N, Katayama T, Shigemura K, Fujisawa M, Kawabata M, Hotta H, Shirakawa T (2014) Oral administration of genetically modified Bifidobacterium displaying HCV-NS3 multiepitope fusion protein could induce an HCV-NS3-specific systemic immune response in mice. Vaccine 32:3066-3074

111. Medaglini D, Ciabattini A, Spinosa MR, Maggi T, Marcotte H, Oggioni MR, Pozzi G (2001) Immunization with recombinant Streptococcus gordonii expressing tetanus toxin fragment $C$ confers protection from lethal challenge in mice. Vaccine 19:1931-1939

112. Marelli B, Perez AR, Banchio C, de Mendoza D, Magni C (2011) Oral immunization with live Lactococcus lactis expressing rotavirus VP8 subunit induces specific immune response in mice. J Virol Methods 175:28-37

113. Hanniffy SB, Carter AT, Hitchin E, Wells JM (2007) Mucosal delivery of a pneumococcal vaccine using Lactococcus lactis affords protection against respiratory infection. J Infect Dis 195:185-193

114. Lee JS, Poo H, Han DP, Hong SP, Kim K, Cho MW, Kim E, Sung MH, Kim CJ (2006) Mucosal immunization with surface-displayed severe acute respiratory syndrome coronavirus spike protein on Lactobacillus casei induces neutralizing antibodies in mice. J Virol 80:4079-4087

115. Sun $P$, Zhang $X$, Zang $X$, Zhou $X$, Chen $Y$, Arunakumara KK, Liang $B$ (2007) Anti-hypercalcemic effect of orally administered recombinant Saccharomyces cerevisiae expressing salmon calcitonin on hypercalcemic rats. Biotechnol Lett 29:1013-1018 